Parliament, Commission, and Council looks just as unlikely as 90/220 to unblock the political moratorium placed by national environment ministers on the release of GMOs. As one senior official in the Environment Directorate-General of the Commission has coyly put it, "Fifteen environment ministers can't all be wrong

There is a certain symmetry in the apportioning of blame for the regulatory impasse. European Parliamentarians think the Commission has been "fragile" with respect to biotechnology. Commission officials characterize industry's lack of response to irrational demands from environmental lobbyists as "appeasement" — an approach that has thus far failed to deliver any significant positive prospects for Europe's biotechnology enterprizes. John Purvis agrees that industry groups

have " not put their best feet forward" and have contented themselves by moving their businesses outside Europe. The industry representative groups say the EU member states "cannot get it together" while those national governments call on more action from the European institutions

John Purvis believes that the trade implications of a continued moratorium on the importation and use of GM crops will bring things to a head. Before US president George W Bush announced his intention to step back from the Kyoto agreement, American diplomats had been indicating that GM crop and cosmetics would be the two main problem areas in EU-US trade and that both of them would make the recently resolved dispute over bananas look like a child's game.

John Hodgson, London

\title{
Big pharmas seek biotechs that deliver
}

In its biggest acquisition ever, pharmaceutical giant Johnson \& Johnson (J\&J; New Brunswick, NJ) announced on 26 March that it plans to absorb drug delivery pioneer Alza (Mountain View, CA) in a stock-for-stock deal valued at $\$ 10.5$ billion. The news had an immediate effect on Alza shares, which jumped $25 \%$ to around $\$ 38$ after the announcement. Although analysts say the deal reflects a broader appreciation of the importance of drug delivery technology by pharmaceutical companies, they do not expect to see a general surge in acquisitions of drug delivery firms.

Announcing the deal, J\&J vice chair William Weldon asserted that "as a world leader in drug delivery technologies, Alza will bring us significant new product opportunities and will enable us to extend product life-cycles." The latter issue is becoming acutely important for pharmaceutical companies, according to Don Ellis, an analyst at Thomas Weisel Partners (San Francisco, CA). "Over the next three to four years, there is roughly $\$ 30$ billion in drugs losing patent protection, so there's a lot of pressure on big pharma to maintain revenue and earnings growth." For example, J\&J's antipsychotic drug Risperdral, which is currently given in two to four doses a day, could be developed with Alza delivery technology into a once-a-day formulation to help it compete against Pfizer's new schizophrenia drug, Geodon. Other Alza technologies include transdermal patches and implants that could be used to extend the lifespans of a variety of other J\&J products now facing patent expiration or new competition. "The potential for application of drug delivery [to existing drugs] is just enormous, [and] there's very little risk because all of the toxicology is well-known to the FDA," says Ellis.

Alza, which will continue to operate as an independent unite, also stands to benefit from the J\&J deal. Although the company earned \$233 million last year, and is currently profitable with over a dozen products on the market, analysts say Alza faced serious hurdles over the next few years. In particular, Concerta, its gradual-release version of Ritalin for attention-deficit-hyperactivity disorder, and Ditropan XL, its incontinence drug, are expected to be outgunned by Celltech, Shire, Novartis, and Pharmacia, which have all launched competing products. Moreover, although Alza has 8 products in its pipeline, the most advanced (Etrans-fentanyl for treating acute pain) is not due to launch until mid-2003. Gaining the sales and marketing power of J\&J should help Alza compete with its new rivals while it develops its pipeline.

Meanwhile, the development of new protein and DNA-based drugs that cannot be delivered by traditional methods is driving increasing demand for new delivery technologies. "For new compounds out of the biotech industry this will become the sine qua non. You will not be able to get a product unless you have some sort of device component to it," says Felix Theeuwes, chair and chief scientific officer of drug delivery firm Durect (Cupertino, CA), which was originally spun off from Alza and is focused on therapies for chronic pain. Theeuwes says that large companies without drug delivery platforms will either have to develop or buy new technology. "There was a time that drug delivery seemed like a good idea but you couldn't give it away. . .now it's on everybody's mind and in everybody's strategic plan."

However, while interest in drug delivery technology is clearly increasing, there is unlikely to be a rush to purchase drug delivery firms. "I think there are going to be a lot of drug delivery companies that are saying 'hey, me too', as soon as this [acquisition of Alza] is consummated," says Kenneth Colley, founder and CEO of startup Angiogenix (Burlingame, CA), but “...the $\$ 10$ billion acquisition is not what [drug delivery companies] should all expect."

Colley says that tool companies reliant on delivery technology alone "are going to face a real uphill battle" as the competition for pharmaceutical company partnerships becomes more intense. "Alza is more than meets the eye," he says, pointing out that although initially focused exclusively on delivery systems, the company has also had a drug development pipeline since 1993 and its drug portfolio is expected to generate $\$ 725$ million in 2001, well over half its total 2000 revenue of $\$ 988.5$ million. Small preclinical-stage drug delivery companies should try to emulate that model, says Colley. For its part, Angiogenix is developing a system to treat ischemic diseases of the heart-a process that involves both identifying growth factors that induce arteriogenesis and devising ways of delivering the proteins.

While small companies like Angiogenix, which have no products and are years away from profitability, may be pleased if the J\&J/Alza deal prompts big pharma to go on a shopping spree, others that have launched products already or expect to do so soon may prefer to remain independent. One such company is Alza spinoff Durect, which plans to launch its first product in 2003. "We as a company would prefer to remain separate," says president and CEO James Brown, "we didn't spend this time focusing to get the company [spun off from Alza] just to roll it back onto a larger balance sheet."

Other, larger, drug delivery companies are unlikey to be bought out simply because of the complicated structure of their partnerships. Elan (Dublin, Ireland), for example, "has so many relationships with so many different drug companies, and they're so complex financially," that they would be too difficult to acquire, according to Ellis.

J\&J's acquisition of Alza is subject to antitrust review in the US and Europe, but Ellis and other analysts expect the deal to be approved by shareholders and proceed as scheduled in the third quarter of 2001.

Alan Dove, Philadelphia, PA 